\title{
Soybean Sudden Death Syndrome Caused by Fusarium virguliforme is Impaired by Prolonged Flooding and Anaerobic Conditions
}

N. A. Abdelsamad, Department of Plant Pathology and Microbiology; J. Baumbach and M. K. Bhattacharyya, Department of Agronomy; and L. F. Leandro, Department of Plant Pathology and Microbiology, Iowa State University, Ames 50010

\begin{abstract}
High soil moisture usually favors soybean sudden death syndrome (SDS), caused by Fusarium virguliforme $(F v)$, but the effects of the duration of the flooding period and accompanying anaerobic conditions on the soybean- $F v$ interaction are not clear. Greenhouse studies were conducted using susceptible and resistant cultivars exposed to the following treatments: 3,5 , or 7 days of continuous flooding, repeated short-term flooding of $8 \mathrm{~h} /$ week for 3 weeks, and a no-flood check treatment. At 7, 14, and 21 days after flooding (DAF), seedlings in the noflood, 3-day, and repeated short-term treatments showed the highest root rot and foliar symptom severity, whereas seedlings in the 7-day treatment showed the lowest severity. $F v$ inoculum density in soil

was lowest in the 7-day flooding treatment. In a hydroponic system, the steady transcript levels of soybean defense genes and $F v$ candidate virulence genes were measured in response to different oxygen levels using qPCR. $F v$-infected roots exposed to $12 \mathrm{~h}$ of anaerobic conditions showed down-regulation of the defense-related soybean genes $\mathrm{Lac}$ case, PR3, PR10, PAL, and $C H S$, and the $F v$ virulence genes pectate lyase $(P L)$, and $F v$ homolog of the pisatin demethylase (PDA). Our study suggests that short-term flooding tends to increase SDS, while prolonged flooding negatively impacts SDS due to reduction of $F v$ density in soil. Moreover, anaerobic conditions down-regulate both soybean defense genes and $F v$ candidate virulence genes.
\end{abstract}

Soybean [Glycine max (L.) Merrill] sudden death syndrome (SDS), caused by the soilborne fungus Fusarium virguliforme $(F v)$, is a devastating disease in North and South America (Covert et al. 2007). In the last two decades, SDS has been ranked among the top 10 soybean diseases in the United States with average economic losses estimated at 190 million dollars annually between 1999 and 2004 due to yield reduction (Leandro et al. 2012; Wrather and Koenning 2006). Under cool, wet soil conditions, the fungus causes root rot and reduces root biomass. Later in the season, usually during soybean reproductive stages, the fungus secretes toxins that cause foliar interveinal chlorosis, necrosis, premature defoliation, and pod abortion (Jin et al. 1996; Roy 1997). SDS epidemics are highly dependent on environmental conditions, such as temperature and high soil moisture, both at vegetative and reproductive growth stages (Gongora-Canul and Leandro 2011; Leandro et al. 2013; Scherm et al. 1998; Scherm and Yang 1996). Thus, understanding the effect of temperature and high soil moisture on the $F v$-soybean interaction is important for improving SDS disease management strategies, which currently rely primarily on the use of host resistance (Hartman et al. 2015).

Flooding stress due to excess rainfall and/or poorly drained soil is considered the second most damaging abiotic stress to crop production after drought (Bailey-Serres and Colmer et al. 2014; Mittler and Blumwald 2010; Setter and Waters 2003). In the United States, waterlogging adversely affects about $16 \%$ of soils (Boyer 1982). Soybean is highly sensitive to flooding stress (Wuebker et al. 2001); pre-emergence flooding for as few as $24 \mathrm{~h}$ can reduce emergence by $50 \%$, and flooding at early vegetative or reproductive stages reduces soybean yield by up to $43 \%$ and $56 \%$, respectively (Scott et al. 1989; Sullivan et al. 2001). In addition, flooding and saturated soils can predispose soybeans to pathogen infection (Bostock et al. 2014; Dorrance et al. 2003a; Kirkpatrick et al. 2006b, 2006a). For example, root rot and damping-off caused by Pythium spp., Phytophthora spp., Rizoctonia

Corresponding author: L. F. Leandro; E-mail: lleandro@iastate.edu

*The $\boldsymbol{e}$-Xtra logo stands for "electronic extra" and indicates that one supplementary table is published online.

Accepted for publication 21 December 2016.

C) 2017 The American Phytopathological Society solani, and Fusarium spp. are more severe in flooded or high soil moisture fields than in nonflooded fields (Dorrance et al. 2003b; Kirkpatrick et al. 2006b, 2006a). Similarly, wet soils, irrigated fields, and years with above-average rainfall or flooding events favor SDS (de Farias Neto et al. 2006; Leandro et al. 2013; Melgar et al. 1994; Scherm and Yang 1996), and major outbreaks in Iowa have coincided with years of extreme flooding: 1993, 2008, and 2010 (Leandro et al. 2013). However, there is no information about how and why excessive soil moisture is associated with severe SDS, nor how soybeans respond to these conditions.

Flooding triggers a decrease in oxygen levels and a build-up of $\mathrm{CO}_{2}$ and toxic compounds in the root zone (Boru et al. 2003; Kozlowski 1984). In soybean, lack of oxygen supply is accompanied by inhibition of respiration and mineral uptake, reduction in leaf photosynthesis, suppression of root nodulation, root injuries, and reduced growth and development (Henshaw et al. 2007; Linkemer et al. 1998). Flooding or low-oxygen stress causes down-regulation of genes involved in biosynthesis of phenylpropanoids, lignin, and flavonoids, which play important roles in defense against plant pathogens (Nanjo et al. 2011). Suppression of root growth and lateral root formation were also observed in flooded soybean due to down-regulation of genes involved in cellulose synthesis (Nanjo et al. 2011).

To protect themselves against biotic stress, plants possess a battery of defense mechanisms, including physical and chemical barriers to prevent pathogen infection and further spread (Bostock et al. 2014). For example, studies on the soybean- $F v$ interaction (Iqbal et al. 2009; Radwan et al. 2011; Yuan et al. 2008) reported that infected roots had increased transcript levels of defense-related genes, including: (i) pathogenesis-related proteins such as $P R-1, P R-5$, and $P R-10$; (ii) genes associated with the phenylpropanoid pathway such as phenylalanine ammonia lyase (PAL) and chalcone synthase (CHS); and (iii) genes involved in cell wall lignification, such as laccase. On the other side, pathogens produce pathogenicity-related proteins or enzymes and virulence factors to invade their hosts and cause disease (Maor and Shirasu 2005). For instance, $F v$ secretes a low molecular-weight $13.5-\mathrm{kDa}$ acidic protein, named FvToxl, that causes the development of SDS leaf symptoms on soybeans (Pudake et al. 2013). Similarly, the pea pathogens $F$. oxysporum f. sp. pisi and Nectria hematococca (teleomorph of $F$. solani) produce pisatin demethylase (PDA) to detoxify pisatin, a phytoalexin in peas (Coleman et al. 2011). In Alternaria brassicicola, the causal agent of black spot disease of Brassica species, deletion of the pectate lyase $(P L)$ gene reduced virulence by approximately 
$30 \%$ compared with the wild-type strain (Cho et al. 2015). The role of $P D A$ and $P L$ on $F v$ virulence is unknown. Research is also needed to understand how these defense mechanisms are affected during $F v$ infection in combination with the abiotic stress resulting from flooding and low oxygen.

It is unclear if increased SDS disease severity under high soil moisture is caused by physiological stress on soybean, by stimulation of $F v$ activity, or by both factors. In this study, we hypothesized that flooding and the associated reduction in soil oxygen level would increase SDS severity compared with no flooding and normal oxygen conditions. The objectives of this study were to assess the effects of (i) flooding duration on SDS disease development in greenhouse plants and (ii) low oxygen levels in a hydroponic system on the soybean- $F v$ interaction by measuring the expression of the soybean defense genes and $F v$ candidate virulence genes.

\section{Materials and Methods}

Inoculum preparation. $F v$ isolate Mont- 1 was used as the inoculum source in all trials. For spore suspension preparation, cultures were grown on potato dextrose agar media (PDA) for 28 days at room temperature in darkness. Plates were flooded with $20 \mathrm{ml}$ of sterile distilled water, conidia were dislodged with a rubber policeman, and suspensions were filtered through a double layer of sterile cheesecloth. The conidia were quantified using a hemocytometer and adjusted to $10^{6}$ conidial $/ \mathrm{ml}$ using sterile distilled water. Inoculum was prepared following the procedure described by Munkvold and O'Mara (2002). A mixture of sand $(1900 \mathrm{ml})$, corn meal $(380 \mathrm{ml})$, and distilled water $(110 \mathrm{ml}$ ) was autoclaved in $20 \mathrm{~cm} \times 30 \mathrm{~cm}$ bags (Fisher Scientific, Pittsburg, PA) for $1 \mathrm{~h}$ at $121^{\circ} \mathrm{C}$ on two consecutive days. Each bag was then inoculated with $2 \mathrm{ml}$ of the spore suspension, or with $2 \mathrm{ml}$ of sterile distilled water for controls. The bags were incubated in the dark, at room temperature, for 6 days with daily mixing by hand to keep uniform distribution of the fungus.

Effect of flooding on SDS. Soybean cultivars Williams 82 (susceptible to SDS) and MN1606 (resistant to SDS) were used in all greenhouse experiments. Before planting, the prepared $F v$ inoculum was mixed, at a ratio of 1:10 (v/v), with a 2:1 mixture of pasteurized sand:soil. Noninfested soil was used for controls. Styrofoam cups (236 ml) were filled with the infested mixture, and four seeds were sown per cup, $2 \mathrm{~cm}$ below the soil surface. Plants were grown in the greenhouse at $24^{\circ} \mathrm{C}$ and a 16-h photoperiod, with daily watering to avoid dehydration. At the unifoliate stage (Fehr et al. 1971), seedlings were thinned to two plants per cup, then exposed to different flooding periods by submerging the cups in plastic basins $(88.1 \mathrm{~cm} \mathrm{~L} \times 41.9 \mathrm{~cm}$ $\mathrm{W} \times 15.2 \mathrm{~cm} \mathrm{H}$ ) and maintaining the water level $2 \mathrm{~cm}$ above the soil surface during the flooding periods. The unifoliate stage was selected because soybean are particularly susceptible to flooding stress at this stage (Scott et al. 1989; Sullivan et al. 2001), and to expose the plants to flood stress before SDS foliar symptoms typically appear in greenhouse conditions (Gongora-Canul and Leandro 2011). The flooding treatments were as follows: continuous flooding for 0 days (no-flood control), 3, 5, and 7 days, or a repeated short-term flooding of 8 h/week for 3 weeks. The repeated short-term treatment was applied by exposing the plants to $8 \mathrm{~h}$ of continuous flooding in the first day of each week, and repeating this process for two more weeks (Sah et al. 2006). After each flooding period, the cups were moved to the bench and allowed to drain, and then regular watering resumed. For the noflood control treatment, plants were maintained on the bench and watered as needed to avoid dryness.

A $2 \times 5 \times 2$ factorial experiment encompassed two cultivars (Williams 82 and MN1606), five flooding treatments (no flood, repeated shortterm flooding (RS), and 3, 5, and 7 days), and two $F v$ inoculation levels (inoculated and noninoculated) in a completely randomized design. There were 10 replicate cups per treatment combination for each of three assessment times and the experiment was conducted three times. Twenty plants (two per each of 10 cups) were destructively sampled and used for root rot and foliar disease ratings 7, 14, and $21 \mathrm{DAF}$ (days after start of flooding). Root rot and foliar symptom severity were rated visually as the percentage of root area showing brown or black discoloration, and percentage of leaf area showing chlorosis and/or necrosis, respectively. Area under the disease progress curve (AUDPC) was calculated for SDS foliar and root rot severity (Simko and Piepho 2012). Root and shoot dry weight were measured on five arbitrarily selected plants (one per cup) by rinsing in tap water to remove soil particles, and drying the root and shoots separately in an oven at $70^{\circ} \mathrm{C}$ for 1 or 2 days.

$F v$ population density in soil was assessed in three randomly selected cups planted with Williams 82, following protocols of Rupe et al. (1997). One gram of soil was placed in $100 \mathrm{ml}$ of sterile distilled water in a $250-\mathrm{ml}$ flask, and 10-fold serial dilutions were prepared ranging from $10^{-1}$ to $10^{-3}$. A volume of $0.2 \mathrm{ml}$ was transferred from each $10^{-3}$ dilution and spread over two plates of modified Nash and Snyder's medium (MNSM) using a rubber policeman. The $10^{-3}$ dilution was used as it showed countable number of $F v$ colonies in preliminary tests. There were a total of 6 plates ( 3 cups $\times 2$ plates) per treatment. The plates were incubated at room temperature for 5 days in the dark, and the numbers of colonies obtained were used to calculate the number of colonies forming units per gram of soil (CFU/g soil).

Effect of oxygen level on the soybean $-F v$ interaction. To examine the effect of anaerobic (no oxygen) and hypoxic (low oxygen) conditions on the soybean- $F v$ interaction, we analyzed the expression of selected host defense related genes and $F v$ candidate virulence genes in $F v$-inoculated soybean roots subjected to different oxygen levels, as described below. Soybean defense related genes studied were $\mathrm{Lac}$ case, $P R-3, P R-10, P A L$, and $C H S$. Fv virulence genes studied were FvToxl, $P D A$, and $P L$. The $P D A$ and $P L$ genes were selected because they are homologs of genes with known virulence functions in the pea pathogens $F$. oxysporum f. sp. pisi and $N$. hematococca. For instance, pisatin demethylase is an enzyme produced by microbial pathogens such as $F$. oxysporum to detoxify the plant phytoalexin pisatin (Coleman et al. 2011). Pectate lyase is an pectin-digesting enzyme that plays important role in pathogen invasion and colonization of host tissue by degrading pectin in plant cell walls and middle lamellae (Cho et al. 2015).

Validation of the PDA and PL genes predicted to be involved in $\mathrm{Fv}$ virulence. An experiment was conducted to analyze the differential expression of $F v$ candidate virulence gene $P D A$ and $P L$ in mycelia, germinated conidia, and soybean roots. The Mont- 1 isolate was maintained on Bilay agar plates $[(0.1 \% \mathrm{KH} 2 \mathrm{PO} 4(\mathrm{w} / \mathrm{v}), 0.1 \%$ KNO3 (w/v), $0.05 \%$ MgSO4 (w/v), $0.05 \% \mathrm{KCl}(\mathrm{w} / \mathrm{v}), 0.02 \%$ starch (w/v), $0.02 \%$ glucose (w/v), $0.02 \%$ sucrose (w/v), and $2 \%$ agar $(\mathrm{w} / \mathrm{v})]$ and subcultured on $1 / 3$ PDA agar plates $[0.04 \%$ potato starch $(\mathrm{w} / \mathrm{v}), 0.2 \%$ glucose $(\mathrm{w} / \mathrm{v}), 2 \%$ agar $(\mathrm{w} / \mathrm{v})]$.

To prepare infected plant material, soybean cultivar Williams 82 was sown in plastic containers $(50.8 \mathrm{~cm} \mathrm{~L} \times 26.67 \mathrm{~cm} \mathrm{~W} \times 6.35 \mathrm{~cm} \mathrm{H})$ containing coarse vermiculite, and maintained under dark conditions with a temperature schedule of $16^{\circ} \mathrm{C}$ for $8 \mathrm{~h}, 18.2^{\circ} \mathrm{C}$ for $1 \mathrm{~h}, 20.4^{\circ} \mathrm{C}$ for $1 \mathrm{~h}, 22.6^{\circ} \mathrm{C}$ for $1 \mathrm{~h}, 24.8^{\circ} \mathrm{C}$ for $1 \mathrm{~h}, 27^{\circ} \mathrm{C}$ for $8 \mathrm{~h}, 24.8^{\circ} \mathrm{C}$ for $1 \mathrm{~h}$, $22.6^{\circ} \mathrm{C}$ for $1 \mathrm{~h}, 20.4^{\circ} \mathrm{C}$ for $1 \mathrm{~h}, 18.2^{\circ} \mathrm{C}$ for $1 \mathrm{~h}$. Seven-day-old seedlings were uprooted, and vermiculite was gently washed from roots with tap water. Three seedlings were placed in a $50-\mathrm{ml}$ conical tube with $25 \mathrm{ml}$ of a $F v$ conidial suspension $\left(10^{6}\right.$ conidia/ml $)$. For the noninoculated control plants, roots were immersed in $25 \mathrm{ml}$ of sterile water. Seedlings were incubated at $22^{\circ} \mathrm{C}$ in the dark for $1,3,5$, and 10 days after inoculation (DAI). The experiment was set up as a $2 \times 4$ factorial, with two $F v$ inoculation levels $\left(10^{6}\right.$ conidia/ml and 0 conidia/ml) and four sampling times $(1,3,5$, and $10 \mathrm{DAI})$, in a completely randomized design. For each sampling time, the roots of the three seedlings in each tube were pooled, immediately frozen in liquid nitrogen and stored in $-80^{\circ} \mathrm{C}$ until RNA preparation. The experiment was repeated two more times.

To prepare $F v$ mycelia, plugs from an $F v$ culture in solid Bilay media were transferred to liquid modified Septoria media (MSM) (Jin et al. 1996), and incubated in darkness, at room temperature, for 2 weeks. The mycelia were then harvested, liquid medium removed by vacuum filtration, and dried mycelial tissues immediately frozen in liquid nitrogen, and stored in $-80^{\circ} \mathrm{C}$ until use for RNA preparation. To obtain germinating conidia, conidia were harvested from 1/3-strength PDA plates and germinated in $10 \mathrm{ml} \mathrm{MSM}$ for $12 \mathrm{~h}$. Conidia were centrifuged for $5 \mathrm{~min}$ at $6000 \mathrm{~g}$ and supernatant was removed. Conidia were washed 
2 times with distilled water to remove residual media. Washed conidia were used directly for RNA preparation. For each sampling time, there were three replicate flasks of MSM for growing mycelium, and three replicate plates of 1/3-strength PDA for collecting conidia.

Hydroponic experiment. A hydroponic system was established under controlled environment to investigate the effect of different oxygen levels on soybean defense related genes and $F v$ candidate virulence genes. Soybean seeds of the SDS resistant and susceptible varieties were sown in $236 \mathrm{ml}$ Styrofoam cups filled with sand-soil mixture infested with $F v$ as described above. The plants were then incubated at $24^{\circ} \mathrm{C}$ with a photoperiod of $16 \mathrm{~h}$ until the unifoliate stage (10 to 12 days after planting) to allow infection to occur. The preinfected seedlings were then transferred to plastic containers (5.6 liters) containing 4 liters of full-strength Hoagland's nutrient solution (MP Biomedicals, LLC, Santa Ana, CA). Seedlings were supported by a perforated Styrofoam sheet through which the root system was suspended in the solution.

The experiment consisted of three oxygen level treatments: (i) normal air conditions $\left(21 \% \mathrm{O}_{2}\right)$; (ii) hypoxic conditions $\left(4 \% \mathrm{O}_{2}+10 \%\right.$ $\left.\mathrm{CO} 2+86 \% \mathrm{~N}_{2}\right)$; and (iii) anaerobic conditions $\left(0 \% \mathrm{O}_{2}, 100 \% \mathrm{~N}_{2}\right)$. Plants were kept in the nutrient solution trays $24 \mathrm{~h}$ before exposure to the gas treatments to allow adaptation to the hydroponic environment. The gas treatments were injected from premixed gas cylinders (Praxair Technology, Inc., Des Moines, IA) and bubbled into the nutrient solution. For each gas treatment, there were two plastic containers, each with 12 plants ( 3 replicate plants $\times 2$ varieties $\times 2$ sampling times).

Seedlings were collected at 6 and $12 \mathrm{~h}$ after the start of exposure to the oxygen treatments. In order to validate the hydroponic system, oxygen concentration of the nutrient solution was monitored using an oxygen meter (model MW600, Milwaukee instruments, Milwaukee, WI). In addition, the expression level of the anaerobic marker gene alcohol dehydrogenase $(A D H 1)$ was measured at 6 and $12 \mathrm{~h}$, and the $\mathrm{pH}$ was adjusted to 4.5 .

The experiment was conducted in three runs. Each run followed a split-plot design with gas treatment (normal, hypoxic, and anaerobic) as the main plot factor, and a $2 \times 2$ factorial combination of sampling times (6 and $12 \mathrm{~h}$ ) and cultivar (resistant and susceptible) as the split plot factor. The resistant cultivar was used in all runs, while the susceptible cultivar was used in runs 2 and 3 only. To quantify change in gene expression of soybean defense-related genes and $F v$ candidate virulence genes, whole roots were collected at 6 and $12 \mathrm{~h}$, and immediately frozen in liquid nitrogen and stored at $-80^{\circ} \mathrm{C}$ until use. At each sampling time, root samples were collected by pooling 3 plants per variety, from each container, resulting in a pooled sample of 6 plants.

RNA extraction and cDNA synthesis for quantification of gene expression using $q P C R$. For RNA extraction, samples were ground to a fine powder in liquid nitrogen, and total RNA was extracted using the RNeasy mini kit (Qiagen, Germantown, MD). DNA contamination was removed using RNase-free DNase I (Invitrogen) following the manufacture's procedure. RNA quantity was determined using a Nano-Drop 1000 spectrophotometer (Thermo Scientific, Wilmington, DE), and integrity was verified on $1 \%$ agrose gel. For cDNA synthesis, $0.5 \mu \mathrm{g}$ of total RNA was reverse transcribed using Superscript III and random hexamers or Oligo (dT) primers (Invitrogen, Carlsbad, CA). Quantitative real-time PCR was performed using Perfecta SYBR Green fast mix (Applied Biosystems, Foster City, CA) and iQ5 detection system (Bio-Rad, Hercules, CA). The reaction mix consisted of $10 \mu \mathrm{l}$ master mix, $0.5 \mu l$ of reverse and forward primers $(250 \mathrm{nM}$ final concentration), $8 \mu \mathrm{l}$ of diluted cDNA, and the final volume was adjusted to $20 \mu \mathrm{l}$ with RNase DNase free water (Invitrogen). The primers used to amplify each gene are shown in Supplementary Table S1. The thermal cycling protocol was $3 \mathrm{~min}$ at $95^{\circ} \mathrm{C}, 40$ cycles of $10 \mathrm{~s}$ at $95^{\circ} \mathrm{C}, 15 \mathrm{~s}$ at primer annealing temperature, and $30 \mathrm{~s}$ at $72^{\circ} \mathrm{C}$, followed by melting curve data collection to check for nonspecific amplification and primer dimers. For gene expression analysis, each treatment had three biological replicates with two technical replicates. Relative gene expression was calculated using the $2^{-\Delta \Delta c t}$ method (Livak et al. 2001), in which the transcript levels of the target genes in normal air-treated seedlings were considered to be the basal levels during expression analysis, and $\beta$-Actin and 18s rRNA were used as internal control genes for host and pathogen, respectively. For validation of $F v$ candidate virulence genes, the transcript levels of the target genes in mycelia were used as the basal level, and FvToxl as internal control gene.

Data analysis. Analysis of variance was performed for each assessment time (7, 14, and $21 \mathrm{DAF})$ using the PROC GLIMMIX procedure of SAS version 9.4 (SAS Institute Inc., Cary, NC) to determine the main effect and interaction of factors on the following variables: root rot and foliar disease severity, $F v$ inoculum density, and plant dry weight matter. PROC GLIMMIX was also used to analyze the AUDPC for root rot and foliar disease severity. For disease severity, flooding treatment and cultivar were used as fixed effects, and replication and run were used as random effects. Data for the noninoculated control were not used in this analysis because the data consisted primarily of zeros. Data for root rot severity (\%), foliar severity (\%), and $F v$ density in soil (cfu/g soil) were available only for inoculated plants. For plant dry weight, data were analyzed for inoculated and noninoculated plants, to determine the effect of flooding alone and in combination with infection by $F v$. Flooding treatment, cultivar, and inoculation were used as fixed effects, and replication and run were used as random effects. Fisher's Protected Least Significant Difference test was used to compare the differences in treatment means for root rot, foliar severity, dry weight, and $F v$ inoculum density among each level of flooding and inoculum at $(P<0.05)$.

Analysis of variance was performed using PROC GLIMMIX on the differential expression (fold change compared with normal air control) of $F v$ candidate virulence genes in mycelia, germinated conidia, and soybean root. The analyses were performed separately for each sampling time, and there were three replications per treatment.

For the hydroponics experiment, analysis of variance was performed using SAS procedure PROC MIXED. Gene expression analyses were performed separately for each sampling time. There was no significant main effect of cultivar and no significant cultivar by oxygen interaction, therefore the analysis was simplified by pooling cultivars. The analysis then treated runs as blocks, so the residual error is the interaction of runs and treatments. For each oxygen treatment, the five observations (three runs for the resistant cultivar, plus two runs for the susceptible cultivar) were averaged together, for each time. Oxygen treatment was used as a fixed effect and the experimental run used as random effect.

\section{Results}

Effect of flooding duration on SDS. Foliar and root rot severity. There was a significant main effect of flooding and cultivar on AUDPC for foliar and root rot severity $(P<0.0001)$. No significant interaction between flooding treatment and cultivar was observed; therefore, data are shown for the main effect of flooding treatment. AUDPC values for foliar and root rot severity were lower $(P<0.001)$ in plants exposed to 5- and 7-day flooding treatments compared with all other treatments (Table 1), but there was no difference between the no-food treatment and the repeated short-term and 3-day flooding treatment (Table 1). However, analysis conducted at each assessment time showed that foliar severity (Fig. 1) was greater in plants exposed to 3-day flooding treatment compared with no flood treatment at $14 \mathrm{DAF}$, whereas root rot was more severe $(P<0.001)$ in plants exposed to 3-day flooding treatment (Fig. 2) compared with no flood treatment at 7 and 14 DAF. Noninoculated plants did not show SDS foliar symptoms and root rot severity was consistently below $10 \%$ in all plants.

Fusarium virguliforme density in soil. Flooding had a significant effect on $F v$ population density in soil used to grow Williams 82 plants $(P<0.0001)$. At 7,14 , and $21 \mathrm{DAF}, F v$ population was lower $(P<0.0001)$ in the 7-day flooding treatment than in all the other treatments (Fig. 3). No difference was observed in $F v$ population in the no-flooding treatment compared with RS, 3-day, and 5-day flooding, at all assessment times, except for 21 DAF when $F v$ density was greater in nonflooded soil compared with 5-day flooding (Fig. 3).

Plant dry weight. There were significant main effects of flooding $(P<0.0001)$ and inoculation $(P<0.0001)$ on root dry weight, but no significant main effect of cultivar. There was also no significant 3 -way interaction between flooding, cultivar, and inoculum $(P>0.48$ at all assessment times), and no significant flooding by cultivar interaction 
at 14 and $21 \mathrm{DAF}(P>0.64)$, except at $7 \mathrm{DAF}(P<0.02)$. Therefore, data are presented with cultivars combined.

In noninoculated plants, flooding significantly affected root dry weight $(P<0.001)$. For instance, at 7 and $14 \mathrm{DAF}$, plants in the noflood and repeated short-term treatments showed greater root dry weight than plants flooded for 5- and 7-days (Fig. 4). In inoculated plants, flooding for 3,5 , or 7 days significantly reduced root dry weight compared with the no-flood treatment at the 7-DAF assessment time only. Furthermore, inoculation with $F v$ reduced $(P<0.001)$ root dry weight in both nonflooded and flooded plants. For instance, at 21 DAF, plants in the no-flood treatment showed up to $76 \%$ reduction in root dry weight relative to noninoculated plants subjected to no flooding (Fig. 4). Moreover, in inoculated plants exposed to flooding,

Table 1. Effect of flooding treatment on SDS development expressed by the area under disease-progress curve (AUDPC) of foliar disease severity and root rot in two soybean cultivars ${ }^{\mathrm{w}}$

\begin{tabular}{llr}
\hline & \multicolumn{2}{c}{ Assessment $^{\mathbf{x}}$} \\
\cline { 2 - 3 } Treatments $^{\mathbf{z}}$ & Foliar & Root rot \\
\cline { 2 - 3 } & \multicolumn{3}{c}{ AUDPC $^{\mathbf{y}}$} \\
\hline No flood & $735.42 \mathrm{a}$ & $752.11 \mathrm{a}$ \\
RS & $804.99 \mathrm{a}$ & $823.91 \mathrm{a}$ \\
5 & $801.16 \mathrm{a}$ & $849.73 \mathrm{a}$ \\
7 & $509.78 \mathrm{~b}$ & $599.07 \mathrm{~b}$ \\
\hline
\end{tabular}

${ }^{\mathrm{w}}$ The data analysis showed no significant interaction between flooding treatment and cultivar; therefore, the resistant cultivar MN1606 and susceptible cultivar Williams 82 were combined for analysis.

${ }^{x}$ Root rot and foliar symptom severity were rated visually as the percentage of root area showing brown or black discoloration, and percentage of leaf area showing chlorosis and/or necrosis, respectively.

y Data represents the mean area under disease progress curve (AUDPC) of SDS foliar disease and root rot severity based on three weekly visual disease ratings at 7,14, and 21 days after flooding in both cultivar. Numbers followed by different letters within the same column are significantly different at $P<0.05$ according to Fisher's least significant difference test.

$\mathrm{z}$ No flood $=$ control; $\mathrm{RS}=$ repeated short term; $3=$ three days of continuous flood; 5 = five days of continuous flood; and $7=$ seven days of continuous flood.

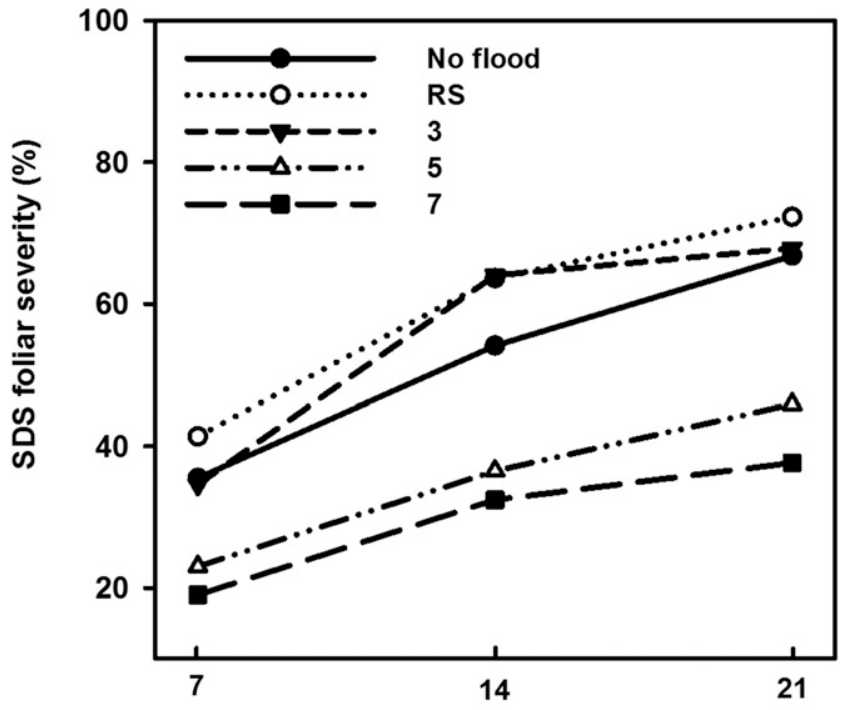

Time (DAF)

Fig. 1. Severity of foliar symptoms of soybean sudden death syndrome in soybean seedlings exposed to no flooding (NF), repeated short-term flooding (RS), and 3, 5, and 7 days of continuous flooding, and assessed 7, 14, and 21 days after start of flooding. Each point represents the mean of 60 replicates (10 cups $\times 3$ runs $\times 2$ cultivars). reduction of root dry weight $(P<0.001)$ was also observed compared with noninoculated plants subjected to flooding, with the highest reduction $84 \%$ observed in repeated short-term flooding treatment at $21 \mathrm{DAF}$. A reduction in root dry weight was also observed in response to inoculation at 7 and $14 \mathrm{DAF}$, but was less pronounced.

For shoot dry weight, there were significant main effects of flooding and inoculation, but no significant effect of cultivar was observed. Also, there was no significant interaction between flooding and cultivar at all rating time points; therefore, cultivars were combined to present the effect of flooding on shoot dry weight. Flooding affected $(P<0.001)$ shoot dry weight of noninoculated plants at all assessment times, but did not affect shoot weight in inoculated plants. For instance, plants exposed to no-flood treatment had higher shoot dry weight compared with 5- and 7-day flooding treatments at all rating time points (data not shown). Moreover, shoot dry weight was lower $(P<0.001)$ in $F v$ inoculated plants compared with noninoculated plants, for all flood treatments and both soybean cultivars, at $21 \mathrm{DAF}$ (data not shown).

Effect of oxygen level on the soybean-Fv interaction. Expression of FV PDA and PL candidate virulence gene homologs. At all time points examined, both genes showed significant up-regulation

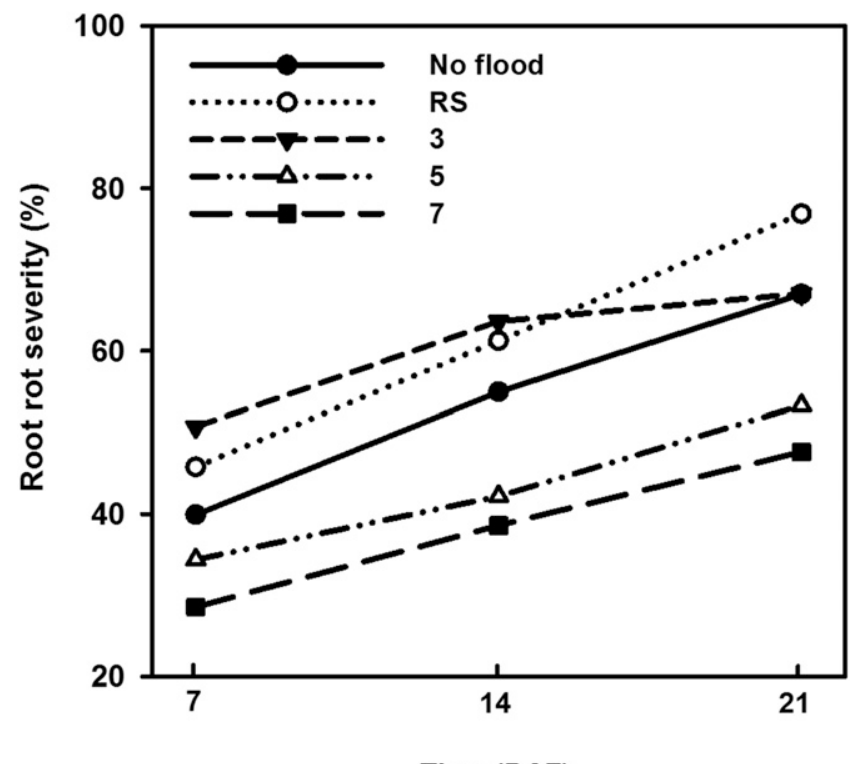

Time (DAF)

Fig. 2. Severity of root rot symptoms of soybean sudden death syndrome in soybean seedlings exposed to no flooding (NF), repeated short-term flooding (RS), and 3, 5, and 7 days of continuous flooding, and assessed 7, 14, and 21 days after start of flooding. Each point represents the mean of 60 replicates (10 cups $\times 3$ runs $\times 2$ cultivars).

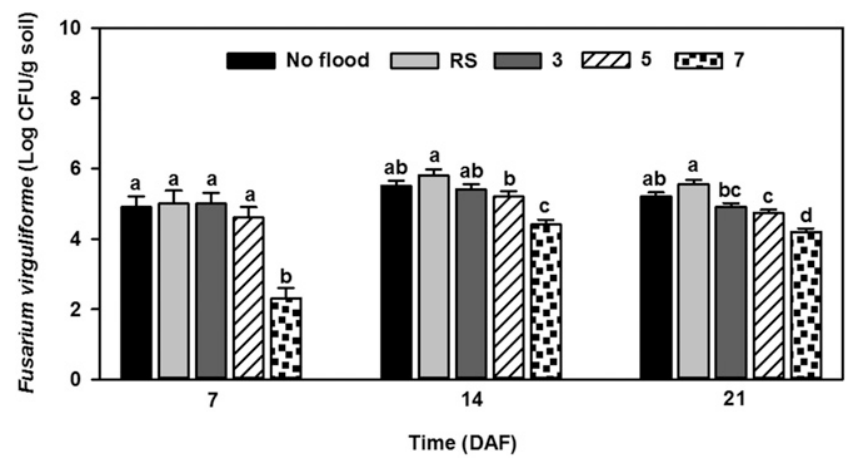

Fig. 3. Population density of Fusarium virguliforme in soil from the Williams 82 cultivar exposed to no flooding (NF), repeated short-term flooding (RS), and 3, 5 , and 7 days of continuous flooding, and assessed 7, 14, and 21 days after start of flooding. Error bar represents the standard error of the mean $(n=9)$. Means with different letters are significantly different $(P<0.05)$. 
in soybean roots compared with mycelia and germinated conidia $(P<$ 0.0001; Fig. 5), suggesting that both genes might be candidate virulence factors for $F v$. Both genes showed different expression patterns over time. For example, PDA had the highest accumulation at $1 \mathrm{DPI}$, with expression declining at later time points, whereas the expression of the $P L$ gene was highest at $10 \mathrm{DPI}$.

Effect of oxygen level on soybean defense related genes in a hydroponic system. At 6 and $12 \mathrm{~h}$, there was a significant $(P<0.01)$ upregulation of the $A D H 1$ anaerobic marker gene under hypoxic and anaerobic conditions compared with normal air, indicating that the hydroponic system was successfully controlled. All defense-related genes tested were down-regulated in roots exposed to anaerobic conditions for $6 \mathrm{~h}$ compared with normal air or hypoxic conditions $(P<$ 0.01 ), except for $P R 10$ where no difference was observed between treatments (Fig. 6). At $12 \mathrm{~h}$, the same pattern was observed in the $\mathrm{Lac}$ case, $P A L$, and $P R 3$ genes $(P<0.01)$, whereas no changes were observed for the $C H S$ and $P R 10$ genes. Gene expression did not differ between hypoxic and normal air conditions for all genes, at both time points.

Effect of oxygen level on $F$. virguliforme genes. At $6 \mathrm{~h}$, significant down-regulation of the PDA and FvToxl genes were observed in roots exposed to anaerobic or hypoxic conditions, respectively, compared with normal air $(P<0.01)$, whereas the $P L$ gene showed no change. At $12 \mathrm{~h}$, all $F v$ genes, except $F v T o x l$, showed significant down-regulation in roots exposed to anaerobic conditions compared

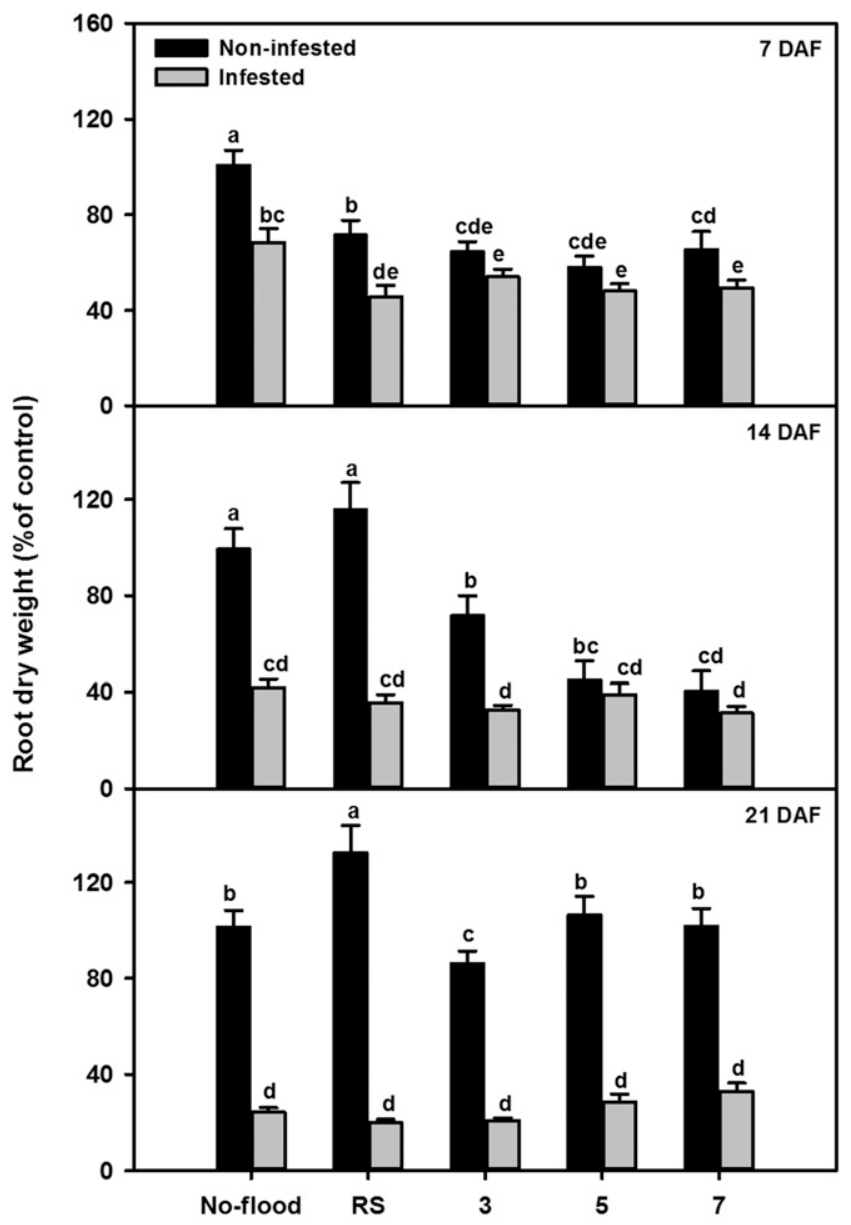

Flooding treatment

Fig. 4. Effect of flooding on root dry weight of soybean cultivars, inoculated or noninoculated with Fusarium virguliforme, at 7, 14, and 21 days after start of flooding (DAF). Columns are the percent mean of root dry weight relative to the noninoculated, no-flooding control. Each bar represents the mean of 30 replicates ( 5 cups $\times 3$ runs $\times 2$ cultivars) and the error bar represents the standard error of the mean $(n=30)$. Columns with different letters are significantly different $(P<0.05)$. with normal air conditions $(P<0.01)$. The expression of $F v$ candidate virulence genes did not differ between normal and hypoxic treatments at both time points, except for FvToxl and $P L$ genes at 6 and $12 \mathrm{~h}$, respectively, where significant down-regulation were observed (Fig. 7).

\section{Discussion}

To the best of our knowledge, this is the first report of the effect of anaerobic and hypoxic conditions on the soybean- $F v$ interaction. This study showed that flooding influences SDS disease severity and $F v$ population density in soil under greenhouse conditions, and that the overall effect on SDS depends on duration of the flooding period. The short-term flooding periods of 3 days and repeated short-term flooding generally predisposed soybean seedlings to SDS, whereas continuous flooding for 5 or 7 days resulted in lower SDS severity. Additionally, this study has shown that low oxygen levels representative of those that might occur during flooding conditions (4\% and $0 \%$ oxygen) generally decreased the expression of soybean defense-related genes and $F v$ candidate virulence genes.

Our findings on short-duration flooding support previous studies demonstrating that high soil moisture favors SDS epidemics (Melgar et al. 1994; Scherm and Yang 1996; Scherm et al. 1998). Our study showed that 3 days of continuous flooding was more conducive to SDS root rot and foliar symptoms than no flooding. This provides experimental support for an observational study (Leandro et al. 2013) suggesting that years with flooding events tended to coincide with the most severe SDS epidemics. However, longer-term flooding of 5 or 7 days resulted in lower AUDPC for foliar and root rot severity compared with the other flooding treatments. This might explain an observation by Rupe and Gbur (1995) that flooding stress during soybean vegetative growth stages could delay or reduce SDS under field conditions. Flooding can also reduce incidence and severity in several other pathosystems. For instance, severity of Verticillium wilt of Chile pepper (Capsicum annuum L.) was less severe under periodic flooding compared with no-flood conditions (Sanogo et al. 2008). Similarly,

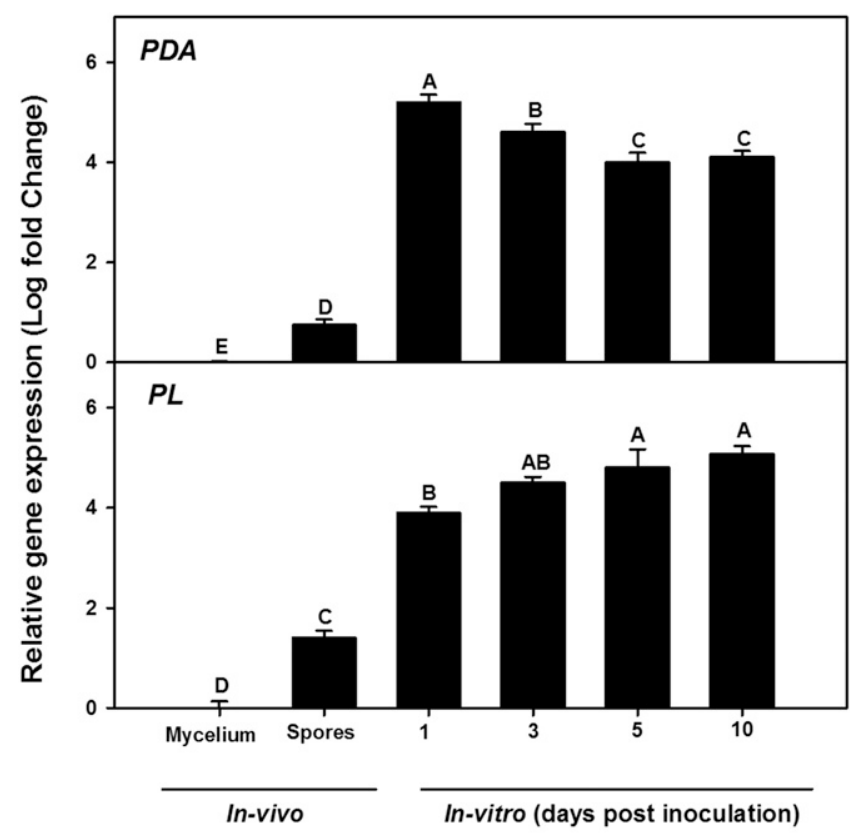

Treatment

Fig. 5. Expression of two candidate Fusarium virguliforme virulence genes, pectate lyase $(\mathrm{PL})$ and pisatin demethylase like (PDA), in mycelia, germinated spores, and Fv-infected soybean roots at $1,3,5$, and 10 days post inoculation. FvTox1 was used as an internal control gene. Each bar represents the mean log-fold change of gene expression for three experimental runs relative to the Fv mycelia. Each treatment has three biological replicates and two technical replicates. Error bar indicates standard error of the mean $(n=3)$. Columns with different letters are significantly different $(P<0.0001)$. 
Singh et al. (2004) showed that rice cultivars grown in flooded conditions were less susceptible rice to leaf blast caused by Pyricularia grisea compared with rice grown upland, where no flooding is used.

Our study suggests that one of the mechanisms underlying the reduction of SDS disease development in long-term flooding might be a reduction in $F v$ density in soil. A reduction in $F v$ CFU/g soil was observed after 5 and 7 days of flooding compared with the shorterduration flooding and no-flood treatments. Previous studies showed that reduction in population density of other Fusarium spp. in flooded soil might be attributed to the effect of anaerobic conditions (Bonanomi et al. 2010; Unger et al. 2009). For example, Ioannou et al. (1977) reported that 40 days of continuous flooding reduced microsclerotia production of Verticillium dahliae, and Niem et al. (2013) showed that 18 weeks of soil flooding at $20^{\circ} \mathrm{C}$ reduced viability of Sclerotinia sclerotiorum sclerotia.

It has been previously reported that flooding at early vegetative stages reduces root and shoot dry weights of soybean (Linkemer et al. 1998). Similarly, in this study, flooding reduced root and shoot dry weights in noninfested plants exposed to 5 and 7 days of flooding compared with no-flood treatment. With the exception of 7 DAF, plants infected by $F \mathrm{v}$ and exposed to flooding showed no difference in root and shoot dry weight compared with the no-flood control. However, for each flooding treatment, infection by $F v$ resulted in an additional reduction in plant dry weight compared with noninoculated plants exposed to the no-flood treatment, suggesting an additive effect of both stresses in reducing soybean root and shoot dry weight. This is consistent with a study by Kirkpatrick et al. (2006a) showing that flooding caused an additive effect in reducing soybean dry weight when plants were infected by Pythium ultimum.

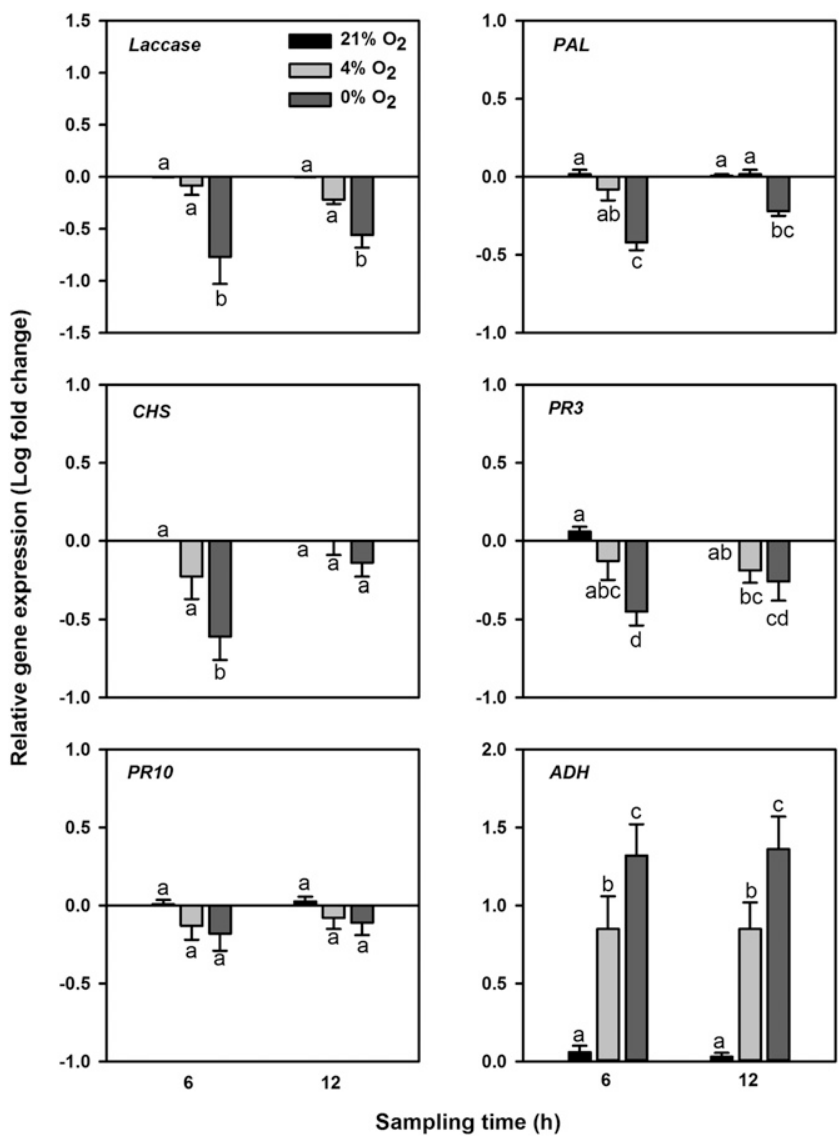

Fig. 6. Effect of oxygen level on the relative expression of soybean defense-related genes in Fusarium virguliforme infected soybean roots at 6 and $12 \mathrm{~h}$ post inoculation (hpi). Beta actin was used as an internal control and the normal oxygen treatment as the calibrator. Each treatment has three biological replicates and two technical replicates. Each bar represents the mean log fold-change of gene expression of three experimental runs, and the error bar indicates standard error of the mean $(n=5)$ averaged over the two soybean cultivars MN1606 and Williams 82. Columns with different letters are significantly different $(P<0.05)$.
At the molecular level, plants subjected to flooding or low-oxygen stresses have been shown to exhibit down-regulation of defense responses, cell wall biosynthesis, and lignification (Drew and Lynch 1980; Nanjo et al. 2011). For example, in soybean, down-regulation

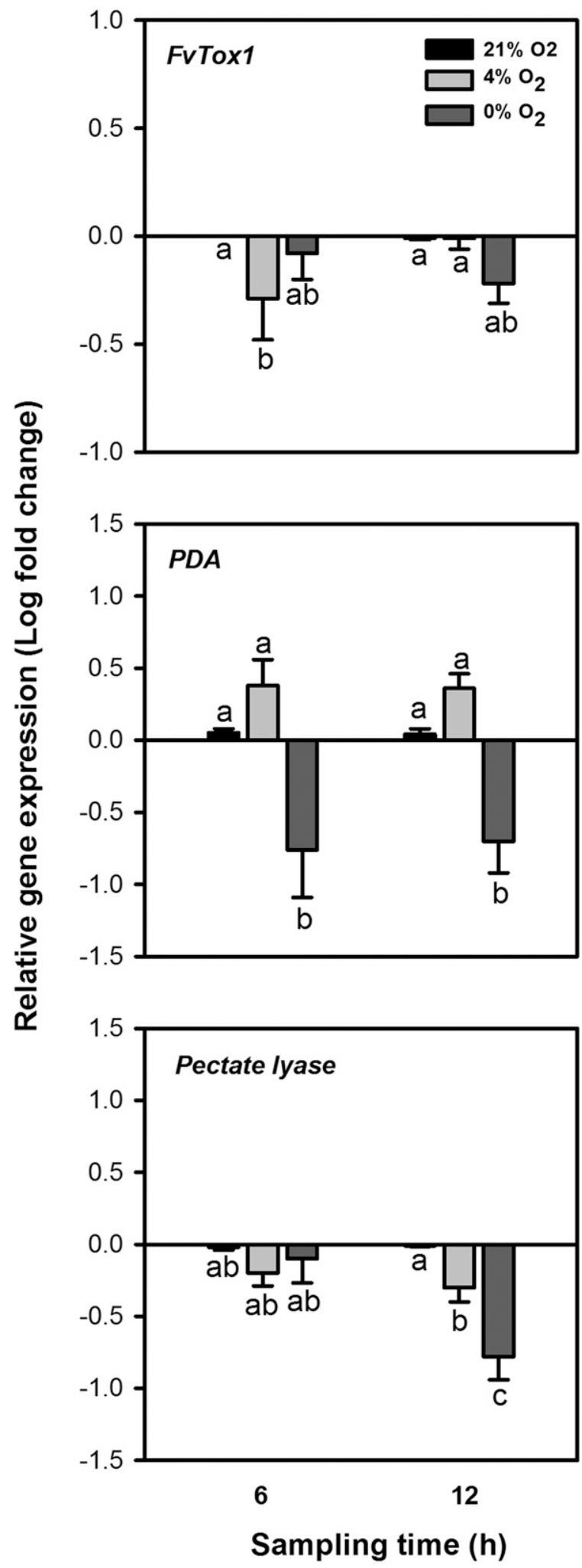

Fig. 7. Effect of oxygen treatments on the expression of Fusarium virguliforme pathogenicity genes in infected soybean roots at 6 and $12 \mathrm{~h}$ post inoculation (hpi). The 18s rRNA gene was used as an internal control and the normal oxygen treatment as the calibrator. Each treatment has three biological replicates and two technical replicates. Each column represents the mean log fold-change of gene expression of three experimental runs. Error bar indicates standard error of the mean $(n=5)$. Columns with different letters are significantly different $(P<0.05)$. 
of genes related to biosynthesis of phenylpropanoids, lignin, and flavonoids were observed under flooding or low-oxygen stresses (Nanjo et al. 2011). Consistent with this, our study showed that anaerobic conditions down-regulated key soybean defense response genes, such as Laccase, PAL, CHS, and pathogenesis-related proteins compared with normal oxygen levels, in inoculated plants. Laccase enzymes play an important role in defense response against fungal infection, including detoxification of fungal toxins and increase of cell-wall lignification (Lozovaya et al. 2006). Laccase gene transcription abundance in $F v$ inoculated roots might play a role in partial resistance against SDSinoculated soybean (Iqbal et al. 2009). Phenylalanine ammonia lyase $(P A L)$ and chalcone synthase $(C H S)$ are key enzymes in the phenylpropanoid pathway that play a crucial role in plant defense against pathogen infection (Yuan et al. 2008). In the soybean- $F v$ interaction, accumulation of $P A L$ and $C H S$ in roots of resistant soybeans has been shown in response to early infection by $F v$ (Iqbal et al. 2005). Pathogenesis-related proteins play important roles in defense response against biotic and abiotic stresses (Xu et al. 2014). As a sign of host defense induction, Radwan et al. (2011) reported accumulation of 31 PR-related genes in roots of $F v$-infected soybeans. Results from our gene expression analysis suggest that down-regulation of some soybean defense-related genes under low-oxygen stress might be involved in the increased susceptibility of soybeans to $F v$ infection under wet soil conditions (de Farias Neto et al. 2006; Scherm and Yang 1996).

From the pathogen side, our study suggests that low-oxygen stress can affect the expression of $F v$ candidate virulence genes, but expression level is dependent on the oxygen concentration and duration of exposure. For instance, two genes tested were down-regulated in $\mathrm{Fv}$ infected soybean seedlings exposed to $12 \mathrm{~h}$ of anaerobic conditions, whereas no changes were observed between hypoxic and normal conditions except for the $P L$ gene. FvToxl is an Fv gene involved in causing SDS leaf symptoms (Pudake et al. 2013). Pisatin demethylase is an enzyme produced by microbial pathogens such as $F$. oxysporum to detoxify the plant phytoalexin pisatin (Coleman et al. 2011). Pecate lyase is an pectin-digesting enzyme that plays an important role in pathogen invasion and colonization of host tissue by degrading pectin in plant cell walls and middle lamellae (Cho et al. 2015).

A previous report showed that the PDA gene was involved in pathogenicity of the pea pathogen $N$. hematococca (Han et al. 2001), which is the closest relative of $F v$ in peas (O'Donnell 2000); however, there was no previous evidence that this gene is important in $F v$. In the present work, we have confirmed that the PDA gene is rapidly induced in infected soybean roots compared with germinating conidia and mycelium, suggesting that it plays a role in $F v$ virulence.

The mechanisms underlying differential regulation of $F v$ candidate virulence genes under low oxygen conditions are not known. Previous studies have shown that some pathogens cannot survive anaerobic stress, while other pathogens can adapt to hypoxic conditions and colonize their hosts. For instance, F. oxysporum, Verticillium dahlia, and S. sclerotiorum were unable to persist and cause disease following 4 to 6 weeks of anaerobic soil disinfestation (Lamers et al. 2010). It is possible that the down-regulation of the $P L$ and $P D A$ genes observed in our study was caused by inability of $F v$ to survive in anaerobic conditions, as also indicated by a reduction in $F v$ density in response to 7 days of flooding. A more comprehensive study is needed to investigate the effect of low-oxygen conditions on more host-defense and $F v$ candidate virulence genes and on disease development.

The results for the repeated short-term and 3-day continuous flooding treatments support our hypothesis that flooding increases SDS severity, but the opposite effect was observed with longer flooding periods. This pattern suggests that the overall effect of flooding on SDS depends on the duration of flooding and on the balance between the direct impacts of flooding on the pathogen and the host. For example, under shortduration flooding, soybeans were already stressed, as indicated by a reduction in dry weight in noninoculated plants, but the $F v$ population was apparently not yet affected. The observed increase in SDS severity maybe therefore has been due to greater predisposition of the stressed plants to high $F v$ levels. Under longer duration flooding, plants were stressed, but $F v$ density and enzyme activity in soil were then also decreased. This resulted in reduced infection of newly formed roots over time, leading to reduced root rot severity (expressed as a percentage of total root area), and reduced foliar symptoms. Furthermore, we observed that anaerobic and hypoxic conditions, representative of those that can occur during flooding stress, adversely affected key host defense response genes, which might explain increased SDS severity in soybean seedlings exposed to 3 days of continuous flooding compared with no flooding.

A limitation of our study is that the effects of flooding and oxygen levels on SDS were tested only on seedlings and under controlled environment conditions. Future work should validate the findings reported here by exposing plants to different flooding durations under field conditions, and also at different growth stages. If flooding is shown to predispose soybean to SDS in field conditions, future research could investigate if flood-tolerant soybean genotypes show enhanced resistance to SDS. Finally, further investigation of the effects of flooding on other factors, such as antagonistic microorganisms and soil physicalchemical properties, are also needed to better understand how flooding affects $F v$ survival and pathogenicity.

\section{Acknowledgments}

This work was funded by the Iowa Soybean Association. We thank Philip Dixon and Sharon Eggenberger for technical assistance in data analyses. We also thank Steven Whitham and Mark Gleason for reviewing the manuscript.

\section{Literature Cited}

Bailey-Serres, J., and Colmer, T. D. 2014. Plant tolerance of flooding stress recent advances. Plant Cell Environ. 37:2211-2215.

Bonanomi, G., Antignani, V., Capodilupo, M., and Scala, F. 2010. Identifying the characteristics of organic soil amendments that suppress soilborne plan diseases. Soil Biol. Biochem. 42:136-144.

Boru, G., Vantoai, T., Alves, J., Hua, D., and Knee, M. 2003. Responses of soybean to oxygen deficiency and elevated root-zone carbon dioxide concentration. Ann. Bot. (Lond.) 91:447-453.

Bostock, R. M., Pye, M. F., and Roubtsova, T. V. 2014. Predisposition in plant disease: exploiting the nexus in abiotic and biotic stress perception and response. Annu. Rev. Phytopathol. 52:517-549.

Boyer, J. S. 1982. Plant productivity and environment. Science 218:443-448

Brar, H. K., Swaminathan, S., and Bhattacharyya, M. K. 2011. The Fusarium virguliforme toxin FvToxl causes foliar sudden death syndrome-like symptoms in soybean. MPMI 24:1179-1188.

Cho, Y., Jang, M., Srivastava, A., Jang, J.-H., Soung, N.-K., Ko, S.-K., Kang, D.O., Ahn, J. S., and Kim, B. Y. 2015. A Pectate Lyase-Coding Gene Abundantly Expressed during Early Stages of Infection Is Required for Full Virulence in Alternaria brassicicola. PLoS One 10:e0127140.

Coleman, J. J., Wasmann, C. C., Usami, T., White, G. J., Temporini, E. D., McCluskey, K., and VanEtten, H. D. 2011. Characterization of the gene encoding pisatin demethylase (FoPDA1) in Fusarium oxysporum. Mol. PlantMicrobe Interact. 24:1482-91.

Covert, S. F., Aoki, T., O’Donnell, K., Starkey, D., Holliday, A., Geiser, D. M., Cheung, F., Town, C., Strom, A., Juba, J., Scandiani, M., and Yang, X. B. 2007. Sexual reproduction in the soybean sudden death syndrome pathogen Fusarium tucumaniae. Fungal Genet. Biol. 44:799-807.

de Farias Neto, A. L., Hartman, G. L., Pedersen, W. L., Li, S., Bollero, G. A., and Diers, B. W. 2006. Irrigation and inoculation treatments that increase the severity of soybean sudden death syndrome in the field. Crop Sci. 46:2547-2554.

Dorrance, A. E., Kleinhenz, M. D., McClure, S. A., and Tuttle, N. T. 2003a Temperature, Moisture, and Seed Treatment Effects on Rhizoctonia solani Root Rot of Soybean. Plant Dis. 87:533-538.

Dorrance, A. E., McClure, S. A., and Martin, S. K. S. 2003b. Effect of partial resistance on phytophthora stem rot incidence and yield of soybean in Ohio. Plant Dis. 87:308-312.

Drew, M. C., and Lynch, J. M. 1980. Soil anaerobiosis, microorganisms, and root function. Annu. Rev. Phytopathol. 18:37-66.

Fehr, W. R., Caviness, C. E., Burmood, D. T., and Pennington, J. S. 1971. Stage of development descriptions for soybeans, Glycine max (L.). Merrill. Crop Sci. 11: 929-931.

Gongora-Canul, C. C., and Leandro, L. F. S. 2011. Effect of Soil Temperature and Plant Age at Time of Inoculation on Progress of Root Rot and Foliar Symptoms of Soybean Sudden Death Syndrome. Plant Dis. 95:436-440.

Han, Y., Liu, X., Benny, U., Corby Kistler, H., and VanEtten, H. D. 2001. Genes determining pathogenicity to pea are clustered on a supernumerary chromosome in the fungal plant pathogen Nectria haematococca. Plant J. 25:305-314.

Hartman, G. L., Chang, H. X., and Leandro, L. F. 2015. Research advances and management of soybean sudden death syndrome. Crop Prot. 73:60-66.

Henshaw, T. L., Gilbert, R. A., Scholberg, J. M. S., and Sinclair, T. R. 2007. Soya bean (Glycine $\max$ L. Merr.) genotype response to early-season flooding: I. Root and nodule development. J. Agron. Crop Sci. 193:177-188.

Ioannou, N., Schneider, R. W., Grogan, R. G., and Duniway, J. M. 1977. Effect of Water Potential and Temperature on Growth, Sporulation, and Production of Microsclerotia by Verticillium dahliae. Phytopathology 67:637-644. 
Iqbal, M. J., Ahsan, R., Afzal, A. J., Jamai, A., Meksem, K., El-Shemy, H. A., and Lightfoot, D. A. 2009. Multigeneic QTL: The laccase encoded within the soybean Rfs2/rhg1 locus inferred to underlie part of the dual resistance to cyst nematode and sudden death syndrome. Curr. Issues Mol. Biol. 11 (Suppl. 1):111-19.

Iqbal, M. J., Yaegashi, S., Ahsan, R., Shopinski, K. L., and Lightfoot, D. A. 2005. Root response to Fusarium solani f. sp. glycines: Temporal accumulation of transcripts in partially resistant and susceptible soybean. Theor. Appl. Genet. 110:1429-1438.

Jin, H., Hartman, G. L., Nickell, D., and Widholm, J. M. 1996. Phytotoxicity of culture filtrate from Fusarium solani, the causal agent of sudden death syndrome of soybean. Plant Dis. 80:922-927.

Kirkpatrick, M. T., Rothrock, C. S., Rupe, J. C., and Gbur, E. E. 2006a. The Effect of Pythium ultimum and Soil Flooding on Two Soybean Cultivars. Plant Dis. 90:597-602.

Kirkpatrick, M. T., Rupe, J. C., and Rothrock, C. S. 2006b. Soybean Response to Flooded Soil Conditions and the Association with Soilborne Plant Pathogenic Genera. Plant Dis. 90:592-596.

Kozlowski, T. T. 1984. Plant Responses to Flooding of Soil. Bioscience 34: 162-167.

Lamers, J. G., Runia, W. T., Molendijk, L. P. G., and Bleeker, P. O. 2010. Perspectives of anaerobic soil disinfestation. Acta Hortic. 883:277-284.

Leandro, L. F., Tatalovic, N., and Luckew, A. 2012. Soybean sudden death syndrome - advances in knowledge and disease management. CAB Rev. 7:1-14.

Leandro, L. F. S., Robertson, A. E., and Mueller, D. S. 2013. Climatic and environmental trends observed during epidemic and non-epidemic years of soybean sudden death syndrome in Iowa. Plant Health Prog. doi:10.1094/ PHP-2013-0529-01-RS.

Linkemer, G., Board, J. E., and Musgrave, M. E. 1998. Waterlogging effects on growth and yield components in late-planted soybean. Crop Sci. 38:1576-1584.

Livak, K. J., Livak, K. J., Schmittgen, T. D., and Schmittgen, T. D. 2001. Analysis of relative gene expression data using real-time quantitative PCR and the $2^{-\Delta \Delta \mathrm{CT}}$ Method. Methods 25:402-408.

Lozovaya, V. V., Lygin, A. V., Zernova, O. V., Li, S., Widholm, J. M., and Hartman, G. L. 2006. Lignin degradation by Fusarium solani f. sp glycines. Plant Dis. 90:77-82.

Maor, R., and Shirasu, K. 2005. The arms race continues: Battle strategies between plants and fungal pathogens. Curr. Opin. Microbiol. 8:399-404.

Melgar, J., Roy, K. W., and Abney, T. S. 1994. Sudden-Death Syndrome of Soybean: etiology, symptomatology, and effects of irrigation and Heterodera glycines on incidence and severity under field conditions. Can. J. Bot. Can. Bot. 72:1647-1653.

Mittler, R., and Blumwald, E. 2010. Genetic engineering for modern agriculture: challenges and perspectives. Annu. Rev. Plant Biol. 61:443-462.

Munkvold, G. P., and O'Mara, J. K. 2002. Laboratory and growth chamber evaluation of fungicidal seed treatments for maize seedling blight caused by Fusarium species. Plant Dis. 86:143-150.

Nanjo, Y., Maruyama, K., Yasue, H., Yamaguchi-Shinozaki, K., Shinozaki, K., and Komatsu, S. 2011. Transcriptional responses to flooding stress in roots including hypocotyl of soybean seedlings. Plant Mol. Biol. 77:129-144.

Niem, J., Gundersen, B., and Inglis, D. a. 2013. Effects of soil flooding on the survival of two potato pathogens, Sclerotinia sclerotiorum and Verticillium dahliae. Am. J. Potato Res. 90:578-590.

O'Donnell, K. 2000. Molecular phylogeny of the Nectria haematococca-Fusarium solani species complex. Mycologia 92:919-938.

Pudake, R. N., Swaminathan, S., Sahu, B. B., Leandro, L. F., and Bhattacharyya, M. K. 2013. Investigation of the Fusarium virguliforme FvTox1 mutants revealed that the FvToxl toxin is involved in foliar sudden death syndrome development in soybean. Curr. Genet. 59:107-117.
Radwan, O., Liu, Y., and Clough, S. J. 2011. Transcriptional analysis of soybean root response to Fusarium virguliforme, the causal agent of sudden death syndrome. Mol. Plant-Microbe Interact. 24:958-972.

Roy, K. W. 1997. Fusarium solani on Soybean Roots : Nomenclature of the Causal Agent of Sudden Death Syndrome and Identity and Relevance of $F$. solani form B. Plant Dis. 81:259-266.

Rupe, J. C., and Gbur, E. E., Jr. 1995. Effect of plant age, maturity Group, and the environment on disease progress of sudden death syndrome of soybean. Plant Dis. 79:139-143.

Rupe, J. C., Robbins, R. T., and Gbur, E. E. 1997. Effect of crop rotation on soil population densities of Fusarium solani and Heterodera glycines and on the development of sudden death syndrome of soybean. Crop Prot. 16:575-580.

Sah, S., Reed, S., Jayachandran, K., Dunn, C., and Fisher, J. B. 2006. The effect of repeated short-term flooding on mycorrhizal survival in snap bean roots. HortScience 41:598-602.

Sanogo, S., El-Sebai, O. I., and Sanderson, R. 2008. Severity of verticillium wilt, plant growth, and spectral reflectance indices of Chile pepper under periodic flooding and no-flooding conditions. HortScience 43:414-419.

Scherm, H., and Yang, X. B. 1996. Development of sudden death syndrome of soybean in relation to soil temperature and soil water matric potential. Phytopathol. 86:642-649.

Scherm, H., Yang, X. B., and Lundeen, P. 1998. Soil variables associated with sudden death syndrome in soybean fields in Iowa. Plant Dis. 82:1152-1157.

Scott, H. D., DeAngulo, J., Daniels, M. B., and Wood, L. S. 1989. Flood duration effects on soybean growth and yield. Agron. J. 81:631-636.

Setter, T. L., and Waters, I. 2003. Review of prospects for germplasm improvemen for waterlogging tolerance in wheat, barley and oats. Plant Soil 253:1-34.

Simko, I., and Piepho, H. P. 2012. The area under the disease progress stairs: calculation, advantage, and application. Phytopathology 102:381-389.

Singh, M. P., Lee, F. N., Counce, P. A., Gibbons, J. H., Barr, H., and Pyricularia, S. 2004. Mediation of partial resistance to rice blast through anaerobic induction of ethylene. Phytopathology 94:819-825.

Sugano, S., Sugimoto, T., Takatsuji, H., and Jiang, C.-J. 2013. Induction of resistance to Phytophthora sojae in soyabean (Glycine max) by salicylic acid and ethylene. Plant Pathol. 62:1048-1056.

Sullivan, M., VanToai, T., Fausey, N., Beuerlein, J., Parkinson, R., and Soboyejo, A. 2001. Crop ecology, production \& management: Evaluating on-farm flooding impacts on soybean. Crop Sci. 41:93-100.

Unger, I. M., Kennedy, A. C., and Muzika, R.-M. 2009. Flooding effects on soil microbial communities. Appl. Soil Ecol. 42:1-8.

Valliyodan, B., Van Toai, T. T., Alves, J. D., de Fátima, P., Goulart, P., Lee, J. D. Fritschi, F. B., Rahman, M. A., Islam, R., Shannon, J. G., and Nguyen, H. T. 2014. Expression of root-related transcription factors associated with flooding tolerance of soybean (Glycine max). Int. J. Mol. Sci. 15:17622-17643.

Wrather, J. A., and Koenning, S. R. 2006. Estimates of disease effects on soybean yields in the United States 2003 to 2005. J. Nematol. 38:173-180.

Wuebker, E. F., Mullen, R. E., and Koehler, K. 2001. Flooding and temperature effects on soybean germination. 41:1857-1861

Xu, P., Jiang, L., Wu, J., Li, W., Fan, S., and Zhang, S. 2014. Isolation and characterization of a pathogenesis-related protein 10 gene $(G m P R 10)$ with induced expression in soybean (Glycine max) during infection with Phytophthora sojae. Mol. Biol. Rep. 41:4899-4909.

Yuan, J., Zhu, M., Lightfoot, D. A., Iqbal, M. J., Yang, J. Y., and Meksem, K. 2008 In silico comparison of transcript abundances during Arabidopsis thaliana and Glycine max resistance to Fusarium virguliforme. BMC Genomics 9 (Suppl 2):S6.

Zhong, Y., Wang, B., Yan, J., Cheng, L., Yao, L., Xiao, L., and Wu, T. 2014. DLb-aminobutyric acid-induced resistance in soybean against Aphis glycines Matsumura (Hemiptera: Aphididae). 9:e85142. 